\title{
LL 論文
}

\section{粘弾性的挙動を示す岩盤の坑道掘進に伴う 時間依存性変形のシミュレーション*}

\author{
緒方 義 弘 ${ }^{1}$ 山. 口 勉 ${ }^{1}$ 屜川 道 雄 $^{2}$ \\ 大久保誠介 ${ }^{3}$ 西松 裕 - ${ }^{4}$
}

\author{
Simulation of Time-dependent Deformation of Visco-elastic \\ Rock Mass around Mine Tunnel being induced by Face Advance \\ by Yoshihiro OGATA ${ }^{1}$, Tsutomu YAMAGUCHI ${ }^{1}$, Michio KURIYAGAWA ${ }^{1}$, \\ Seisuke $\mathrm{OKUBO}^{2}$ and Yuichi NISHIMATSU ${ }^{3}$ \\ 1. National Institute for Resources and Environmet, Onogawa, Tsukuba 305 \\ 2. Faculty of Engineering, The University of Tokyo, Bunkyo-ku, Tokyo 113 \\ 3. Professer Emeritus, The University of Tokyo
}

\begin{abstract}
The time-dependent deformation of weak rock mass around mine tunnel which had been induced by face advance was calculated by two demensional FEM model with non-linear visco-elastic characteristics. The results of simulation agreed well with the measured vertical displacements in roof and convergences of tunnel at Matsumine mine. It is showen in this simulation that if the rock mass behaves as continuous media and the appropriate mechanical parameters are chosen as input parameter, the proposed model can predict the time-dependent deformation of visco-elastic rock mass with only six input parameters within ashort calculation time.
\end{abstract}

KEY WORDS : Time-dependent Deformation, Non-linear Visco-elastic Model, FEM, Tunnel Excavation

\section{1. 緒}

近年，鉱山の分野では軟弱な岩盤内に賦存する鉱床の開発，また 土木の分野では都市の土質軟岩や山岳の膨張性岩盤内へのトンネル の建設等が行われる機会が多く, 岩盤の变形挙動の評価は時間への 依存性を考慮することが重要になってきている。

時間依存性の変形挙動の研究としては, 岩石や岩盤のクリープ現 象の解明と力学モデルの構築 ${ }^{1)}$ が主に行われてきた。また, 最近は 実際の破壊挙動を考慮した三次クリープのモデル化の研究 2 中強度 破壊の予測の試み等 ${ }^{3)}$ 屯行われ，これらのモデルで岩石のクリープ 挙動をある程度忠実に表現できるようになってきている。一方, 実 際の坑道やトンネル等の地下空洞周辺岩盤の変形挙動の研究におい ては, 時間への依存性のみを考慮した解析的手法4) やシミュレーショ ン手法 ${ }^{5) 6)}$ による解析, 時間と切羽進行の両方への依存性を考慮し た解析的手法 ${ }^{7) 8)}$ による解析が行われた例がある。これらでは, 解 析結果を現場での実測結果と対比して, 解析手法の評価を行ってい るが, 岩盤の变形の計測は支保の変形を含めて行われている場合が ほとんぞである。しかし，岩盤の時間に依存した変形挙動を評価し，

\footnotetext{
* 1993 年 12 月 24 日受付 1994 年 7 月 7 日受理 平成 3 年度資源・素材学 会秋季大会で一部発表

1. 正会員 工博 資源環境技術総合研究所地殼工学部

2. 正会員 工博 資源環境技術総合研究所地殼工学部長

3. 正会員 工博 東京大学教授 工学部資源開発工学科

4, 正会員 工博 東京大学名誉教授

キーワード：時間依存性，有限要素法，非線形粘弾性モデル，トンネル掘削
}

解析手法を検討する場合, 基本的には支保の影響を受けていない岩 盤自体の変形挙動を評価すること，また開削前に先行して発生する 変形も考慮することが重要であると考えられる。

著者らは, 軟弱な岩盤内に掘削された坑道周辺岩盤の变形を計測 し, その時間への依存性を評価するとともに, この変形挙動の解析 手法を検討してきた。前者に関しては既に報告したので910)，ここ では, 岩盤の時間依存性の変形挙動の解析手法およびそれの原位置 岩盤の変形への適用の試みについて報告する。

\section{2. 基本的力学モデル}

大久保ら ${ }^{11)}$ は, 一軸圧縮応力下に扔ける岩石の変形挙動のモ゙デ ルとして，(1)式の構成方程式で表わされる非線形粘弾性モデルを 提案している。

$$
\mathrm{d} \lambda / \mathrm{d} t=a \cdot \sigma^{n_{0}} \cdot \lambda^{m}
$$

ここで, $\lambda$ はコンプライアンス, $t$ は時間, $\sigma$ は一軸圧縮応力, $n_{0}$ はひずみ速度と一軸圧縮強度との関係を表わす值, $m$ は強度破壊 後の応力ーひずみ関係を表わす値, $a$ は此例定数である。この構成 方程式の特徵は, 比較的簡単な式であるにも係わらず, 一軸圧縮応 力下における応力緩和試験時の応力挙動やクリープ試験時のひずみ 挙動を統一的に説明できることである。また, 著者らは(1)式を三 軸圧縮応力下に拡張した(2)式を提案している ${ }^{12)}$ 。

$$
\mathrm{d} \lambda^{*} / \mathrm{d} t=a \cdot\left(\Delta \sigma^{*}\right)^{n} \cdot\left(\lambda^{*}\right)^{m}
$$

ここで， $\lambda^{*}$ は初期コンプライアンス $\lambda_{0}$ で正規化した正規化コン プライアンス， $\Delta \sigma^{*}$ は三軸圧縮強度（破壊時の差応力） $\Delta \sigma_{0}$ で 


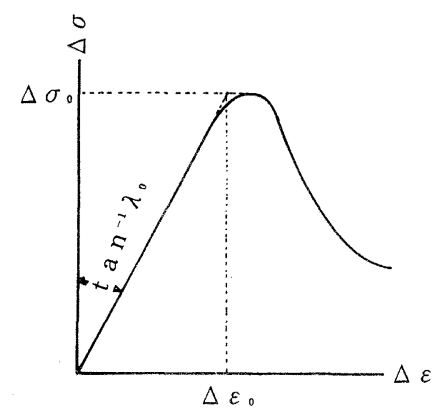

$\Delta \sigma^{*}=\Delta \sigma / \Delta \sigma_{0}$ $\Delta \varepsilon^{*}=\Delta \varepsilon / \Delta \varepsilon_{0}$

Fig. 1 Definition of normalized differential stress and differential strain.

正規化した正規化差応力である。Fig. 1 に $\lambda_{0}, \Delta \sigma^{*}, \Delta \sigma_{0}$, $\Delta \varepsilon_{0}$ および $\Delta \varepsilon^{*}$ の関係を示す。また, 比例定数 $a$ は次の式で表 わすことができる。

$$
a=\left\{m /\left(n_{0}+1\right)\right\}^{m /\left(n_{0}-m+1\right)} / t_{0}
$$

ここで, $t_{0}$ は定ひずみ速度試験を行って強度を求める際に, ひずみ が $\Delta \varepsilon_{0}$ となるまでの所要時間であり， 2 分を用いた。

つぎに, 三軸圧縮強度 $\Delta \sigma_{0}$ と一軸圧縮強度 $\sigma_{c}$, 一軸引張強度 $\sigma_{t}$ およびに周圧 $\sigma_{3}$ との間には Janach の提案した破壊条件 ${ }^{13)}$ が 成立すると仮定した。この破壊条件を用いると,

$$
\Delta \sigma_{0}=\sigma_{c} \cdot\left(1+\sigma_{3} / \sigma_{t}\right)^{0.5}-\sigma_{3}
$$

が得られる。また，(2)式における構成方程式の正規化差応力のべ き乗数 $n$ に対してはつぎの仮定を行った。

$$
n=\left(\Delta \sigma_{0} / \sigma_{c}\right) \cdot n_{0}
$$

ここで, $n_{0}$ は(1)式において一軸圧縮応力下の構成方程式に用いた 一軸圧縮応力 $\sigma$ のべき乗数である。一般に, 周圧が増大するに伴っ て, 三軸圧縮強度 $\Delta \sigma_{0}$ は增大するので，(5)式から計算される $n$ の值む大きくなる。なお, 同じく(1)式で与えられる構成方程式で 用いる定数 $m$ に関しては, 周圧によってその值は変化しないもの とする。さらに，岩石は破壊の進行とともに体積膨張を示すことが 多いため,これを考慮して次の仮定を行った。

$$
\begin{aligned}
& \lambda^{*}<1.5 \rightarrow \nu=\nu_{0} \\
& \lambda^{*}>1.5 \rightarrow \nu=0.49
\end{aligned}
$$

ここで, $\nu_{0}$ は弾性領域でのポアソン比である。

ところで，(2)式で表わす力学モデルでは，応力を受けている岩 盤のコンプライアンスは時間の経過とともに次第に増加していくこ とを仮定している。したがって, この力学モデルを用いた有限要素 法による実際のシミュレーション計算では, 各要素のコンプライア ンスを順次に増加させた繰り返し計算を行うことによって，時間依 存性の変位を求めた。なおその際, ポアソン比 レは, 前述のように,

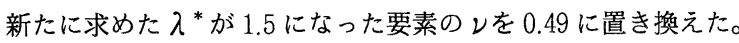

(2)式で表わす力学モデルを用いてシミュレーション計算を行う にあたって, まず計算結果に対して, モデルを構成している諸力学 パラメータの值がどのような影響を与えるかを検証した。シミュレー ション計算には Fig. 2 に示す 2 次元有限要素モデルを用いたが, このモデルは著者らが現場計測を行った松峰鉱山の試験坑道の計測 断面を表わしている。このシミュレーションに用いる岩盤の物性值 等の力学パラメー夕は, 松峰鉱山の坑内で採取した岩石試料で求め た値を参考にして決めた。Table 1に示す力学パラメータのうち, 一軸圧縮強度, 引張強度, 初期コンプライアンス, $n_{0}, m$ および計 算時間の増分（時間の刻みの倍数）の各々を変化させて坑道周辺岩 盤の変形を計算した。なお, 計算は平面ひずみ状態, 地圧は物体力 を考虑した静水圧，初期物性値は全要素一様，坑道は瞬間的に掘削

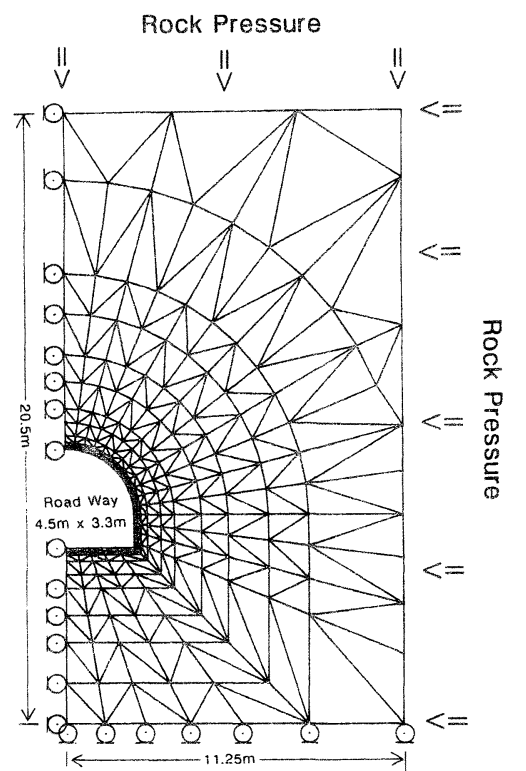

Fig. 2 Elements of FEM model after excavation.

Table 1 Standard physical properties of rock and another parameter.

\begin{tabular}{l|c}
\hline uniaxial compressive strength, $\mathrm{MPa}$ & 6.0 \\
uniaxial tensile strength, $\mathrm{MPa}$ & 0.9 \\
initial compliance, $\mathrm{GPa}^{-1}$ & 0.25 \\
specific gravity, $\mathrm{g} / \mathrm{cm}^{3}$ & 2.5 \\
$n_{0}$ & 10 \\
$m$ & 2 \\
\hline rock pressure $(\mathrm{MPa})$ & 7.5 \\
\hline initial time step calculation (hour) & 2 \\
increment of time step for calculation & 1.02 \\
\hline
\end{tabular}

される等の仮定の下で, 計算結果の評価は松峰鉱山で計測した坑道 の天盤内 $1 \mathrm{~m}$ の䈯所の鉛直方向の変位を対象とした。

力学パラメータの計算結果への影響に関しては, 資源・素材学会 の秋季大会で既に報告しているが ${ }^{14)}$ ，この検証によって，計算結果 を計測結果にあてはめるには, 初期コンプライアンス $\lambda_{0}$ を変化さ せるのが最あ簡便であることが分かった。

\section{3. 妔道周辺岩盤の変形举動人の適用}

\section{3・1 シミュレーションの対象現場および岩盤変形の計測}

シミュレーションの対象とした現場は，松峰鉱山の試験坑道であ り, 計測断面の地質状況を Fig. 3 に示す。なお, 現場計測の結果 とその評価は既に”資源と素材“に発表している ${ }^{910)}$ 。

Fig. 3 に示されるように, 松峰鉱山の試験坑道（同図の L 240roadway）周辺の岩盤は主として石膏，凝灰角磁岩ならびに凝灰 岩より構成されているが, 計測領域内は石亳が大部分を占めている。 また, これらの岩石は含水によって膨潤する性質を持っている。し かし, 試験坑道の掘進時の岩盤は湿潤飽和状態にあるものの, 地下 水等が浸出する状況はなかった。

計測したのは試験坑道の天盤の約 $10 \mathrm{~m}$ 上にある既存坑道の下盤 を基点とした岩盤内鉛直変位, 試験坑道側壁を基点とした岩盤内変 位ならびに試験坑道のコンバージェンスである。特に，天盤内変位 は, 試験坑道の切羽が計測断面に近づき, 通過していく過程, すな わち切羽の移動の影響を考慮した計測を行った。また, 計測は約 500 日間に渡って行われたが，既報で述べたように ${ }^{9)}$ ，地下水の浸 水や周辺坑内の展開等によるもの之思われる影響が変位の経時変化 に現われていたため, 計測結果の解析・評価は計測開始から約 250 日間のデータを対象とした。また，試験坑道のコンバージェンスの 


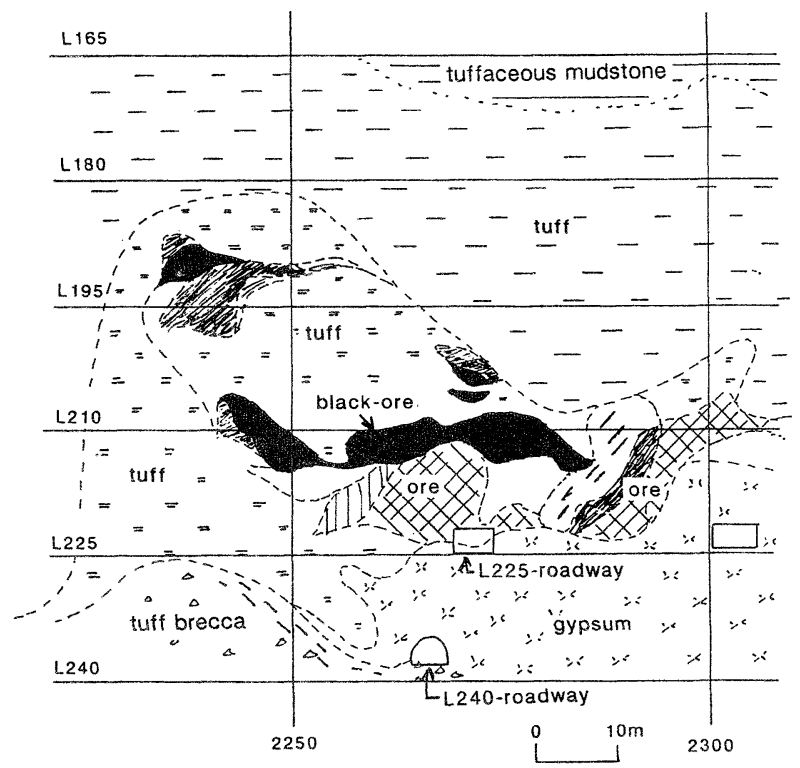

Fig. 3 Geological profile of Matsumine mine.

場合も同様の理由によって, 計測結果の解析・評価は計測開始から 約 100 日間のデータを対象とした。したがって, シミュレーション 解析の適用む同じ計測期間のデー夕を対象とした。

$3 \cdot 2$ 天盤内 $1 \mathrm{~m}$ の変位の経時変化への当てはめ

現場で計測した天盤内変位は, 切羽が計測断面を通過するよりる かなり以前に発生している。また, この天盤内変位は, 各切羽位置 において発生した瞬間的な変位に, 切羽が停止している間に発生し た時間依存性の変位が加わり, 更にこれらが切羽の進行に伴って積 算されたものであり, 坑道掘進による変位と時間に依存した変位と が混在している。一方, 今回のシミュレーション計算では, 坑道は 瞬間的に掘削され, 同時に計算が開始され, その後の時間依存性の 変位のみを求めた。そこで, ここでのシミュレーション計算では, 計算開始時刻を計測された天盤内の変位が顕著に増加し始めた時刻 に便宜上合わせることにした。

まず, 初期コンプライアンス $\lambda_{0} を 0.25 \mathrm{GPa}^{-1}$ から $0.30 \mathrm{GPa}^{-1}$ まで, $0.01 \mathrm{GPa}^{-1}$ の刻みで変化させ, 各々についてシミュレーショ ン計算を行った。この計算で得られた天盤内 $1 \mathrm{~m}$ の鉛直方向変位 の経時変化はFig. 4 に示すとおりである。なお, 天盤内 $1 \mathrm{~m}$ の変 位の経時変化の計測値を Fig. 4 に太い実線で示す。Fig. 4 から明 らかなように, 計測開始から約 150 日目までは, 初期コンプライア ンスを $0.25 \mathrm{GPa}^{-1}$ として計算を行った場合に, 計算値と計測值と がよく合っている。しかし，シミュレーション計算においては, Fig. 4 に示した範囲内のいずれの初期コンプライアンスにおいてす, 天盤内変位は約 30 日目までは急激に增加するものの, それ以降は 変位の増加の割合が徐々に減少する傾向を示す。これに対して, 計 測值は約 35 日目までは急激に増加し, それ以降はほぼ一定の割合 で直線的に増加する傾向を示している。この計測された変位が直線 的に増加する傾向は, 既に報告 ${ }^{9)}$ した変位速度の経時変化の傾向か らも明らかである。なお, 計測の場合には, 天盤内変位が急速に増 加する初期の段階は, 坑道がまだ掘削されていない状態であるので, この時の変位は切羽前方で発生した先行変位である。

ところで, このようなシミュレーションによる計算值を全計測期 間に渡って計測值に合わせることは困難である。そこで, 簡単のた めに, 計算開始から 25 日後, 100 日後および 200 日後の 3 点の経過 時刻における天盤内 $1 \mathrm{~m}$ での変位の計算値を計測值に合わせるこ とにした。すなわち, 各経過時刻における計測値と各々のケースに おける計算值との残差の自乗和を求めた。その結果, 天盤内 $1 \mathrm{~m}$

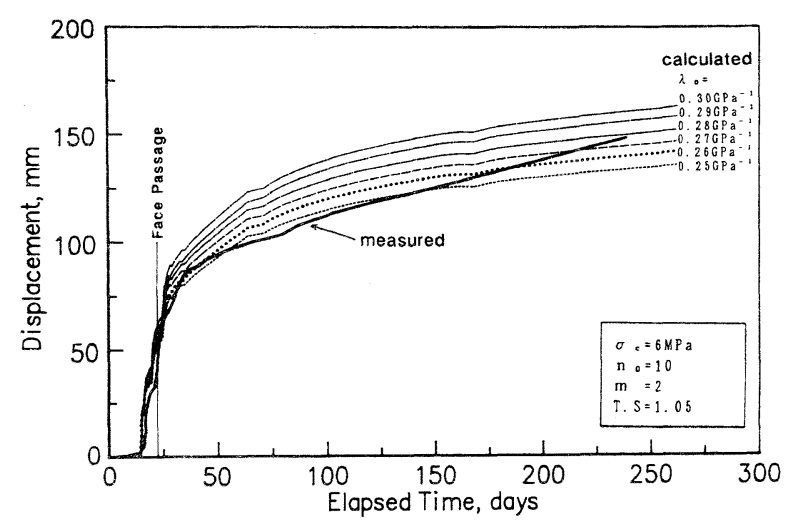

Fig. 4 Comparison between the measured and calculated displacements at $1 \mathrm{~m}$ depth in the roof; initial compliance was ranged from, $0.25 \mathrm{GPa}^{-1}$ to $0.30 \mathrm{GPa}^{-1}$ by every $0.01 \mathrm{GPa}^{-1}$.

の変位は初期コンプライアンスを $0.26 \mathrm{GPa}^{-1}$ とした場合に, 両者 が最もよく合うことが分かった。

つぎに, $0.26 \mathrm{GPa}^{-1}$ の初期コンプライアンスを用いた計算で得 られた天盤内 $1 \mathrm{~m}, 2 \mathrm{~m}$ およよび $3 \mathrm{~m}$ の鉛直方向変位の経時変化を計 測値とと屯にFig. 5 に示す。Fig. 5 から明らかなように，まず天 盤内 $1 \mathrm{~m}$ の変位は, 約 50 日目までの時刻では計算値が計測值を多 少上回る傾向を示すが，両者は比較的よく合っている。しかし，約 50 日目以降は両者が必ずしも合わず，約 200 日目以降は計測值が 計算值より大きくなる傾向を示している。これは, シミュレーショ ン計算では岩盤を連続体として取り扱っているのに対して, 変形が 大きくなったある時刻以降においては，天盤内には大きな開口亀裂 等が発生し，そのため実際の岩盤は不連続体として挙動しているこ とによるものと考えられる。また，初期コンプライアンスを 0.26 $\mathrm{GPa}^{-1}$ として計算した場合の天盤内 $2 \mathrm{~m}$ および $3 \mathrm{~m}$ の変位は, 変 位が急激に増加する初期の段階を含めて, 計算值の方が計測值より 大きく表われている。これはシミュレーション計算を变位の大きい 天盤内 $1 \mathrm{~m}$ の変位の計測結果に当てはめるため, 初期コンプライ アンスを大きくしたことによる。一方, 変位が緩やかな増加に変化 した後は, 計測値および計算值の両方とも天盤内 $1 \mathrm{~m}$ の変位の経 時変化と類似し, 計測値は一定の割合で増加するのに対して, 計算 值は徐々に減少する傾向を示している。

以上のように, シミュレーション計算による天盤内 $1 \mathrm{~m}$ の変位 の経時変化は, 変位が緩やかな增加に変化した後の経時変化が計測 結果とは異なる傾向を示すむのの，初期コンプライアンスを 0.26 $\mathrm{GPa}^{-1}$ にした場合に, 計算結果と計測結果とが最もよく合うこと が分かった。

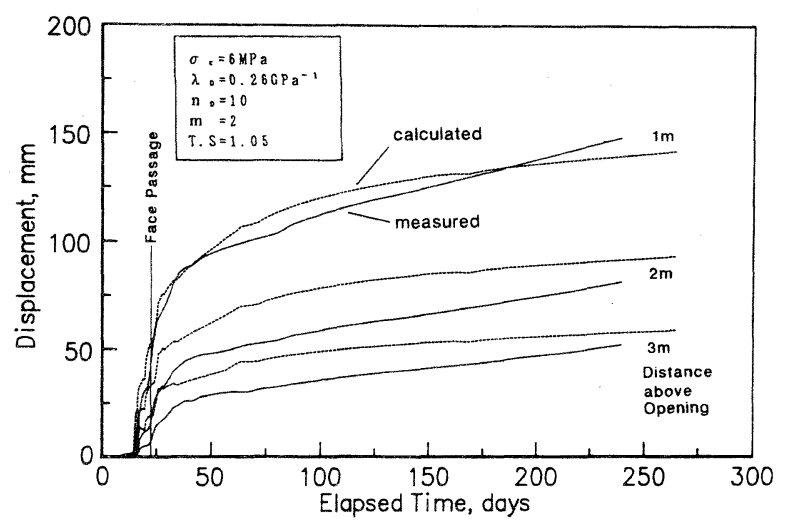

Fig. 5 Comparison between the measured and calculated displacement at $1 \mathrm{~m}, 2 \mathrm{~m}$ and $3 \mathrm{~m}$ depth in the roof; initial compliance was $0.26 \mathrm{GPa}^{-1}$. 


\section{$3 \cdot 3$ 天盤内 $2 m$ の变位の経時変化への当てはめ}

前節では, シミュレーションによる計算結果を天盤内 $1 \mathrm{~m}$ の鉛 直方向変位の計測結果へ当てはめた結果, 天盤内 $2 \mathrm{~m}$ または $3 \mathrm{~m}$ の深さでの変位の経時変化は, 計算值が計測值よりも大きくなるこ とが分かった。これは, 天盤内 $1 \mathrm{~m}$ 付近までの岩盤には大きなゆ るみが発生し, 初期コンプライアンスが増加しているのに対して, 天盤内 $2 \mathrm{~m}$ および $3 \mathrm{~m}$ の岩盤のゆるみは比較的小さく, 初期コン プライアンスの増加む小さいためと考えられる。そこで, ゆるみが 比較的小さいと考えられる天盤内 $2 \mathrm{~m}$ の深さの岩盤の变位を対象 として, 前節の天盤内 $1 \mathrm{~m}$ の変位での当てはめと同一手法により, 計算結果を計測結果に当てはめることにする。

まず，初期コンプライアンスを $0.20 \mathrm{GPa}^{-1}$ から $0.25 \mathrm{GPa}^{-1}$ ま で, $0.01 \mathrm{GPa}^{-1}$ の刻みで変化させ, 各々についてシミュレーショ ン計算を行った。その結果, 天盤内 $2 \mathrm{~m}$ の鉛直方向変位の経時変 化はFig. 6 に示すとおりである。また, 計測した天盤内 $2 \mathrm{~m}$ の変 位の経時変化を Fig. 6 に太い実線で示す。更に, この場合む天盤 内 $2 \mathrm{~m}$ の変位の值を用いて, 3 つの経過時刻における計測值と各々 のケースの計算值との残差の自乗和を求めた結果, 初期コンプライ アンスを $0.21 \mathrm{GPa}^{-1}$ とした場合に, 両者が最も良く合うことが 分かった。そこで, $0.21 \mathrm{GPa}^{-1}$ の初期コンプライアンスを用いて 計算を行い, 天盤内 $1 \mathrm{~m}, 2 \mathrm{~m}$ および $3 \mathrm{~m}$ の鉛直方向変位の経時変 化を計測値とともに Fig. 7 に示す。Fig. 7 から明らかなように, 天盤内 $2 \mathrm{~m}$ の変位を比較すると, 約 30 日目までの変位は計算值が 計測値を上回る傾向を示すが, その後の約 150 日目までは, 計算值 と計測値の経時変化が比較的よく合っている。しかし, 変位が緩や かな増加に変化した後, 計算による変位は増加の割合が時間の経過

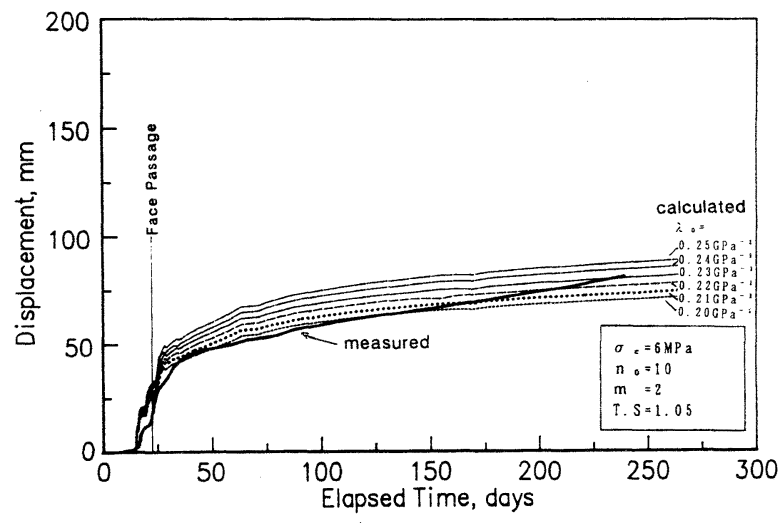

Fig. 6 Comparison between the measured and calculated displacement at $2 \mathrm{~m}$ depth in the roof; initial compliance was ranged from, 0.20 to $0.25 \mathrm{GPa}^{-1}$ by every $0.01 \mathrm{GPa}^{-1}$.

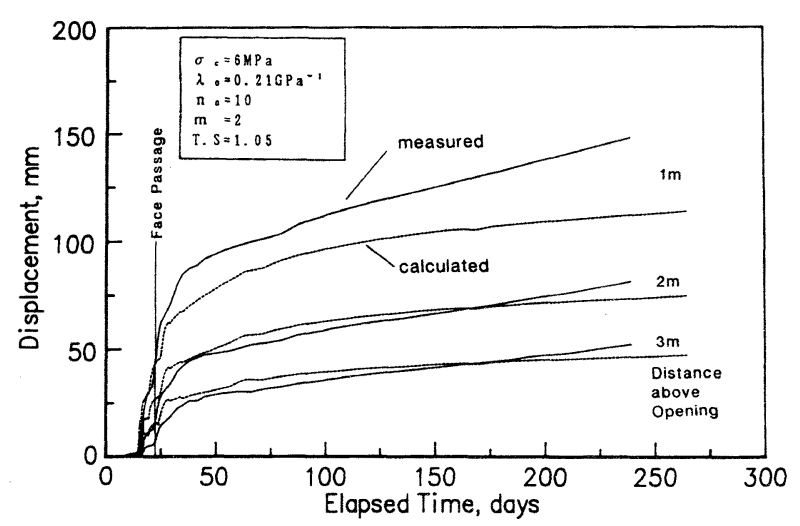

Fig. 7 Comparison between the measured and calculated displacement at $1 \mathrm{~m}, 2 \mathrm{~m}$ and $3 \mathrm{~m}$ depth in the roof; initial compliance was $0.21 \mathrm{GPa}^{-1}$.
に伴って徐々に減少するのに対して, 計測による変位はほぼ一定の 割合で増加するため, 約 180 日目以降は計測值が計算值より大きく なる傾向を示している。このような計算値と計測值の経時変化の相 違は, 天盤内 $1 \mathrm{~m}$ への当てはめと同様の要因によるものと考えら れる。また, 天盤内 $2 \mathrm{~m}$ の変位への当てはめでは, 天盤内 $3 \mathrm{~m} の$ 変位屯計算值と計測值とがよく合っている。これは，天盤内 $2 \mathrm{~m}$ および $3 \mathrm{~m}$ 付近の岩盤には幅るるの発生が見られるものの, 初期 コンプライアンスの増加は小さく, 天盤内 $2 \mathrm{~m}$ と $3 \mathrm{~m}$ 付近の岩盤 は同じような状態であることを示しているものと考えられる。一方, 天盤内 $2 \mathrm{~m}$ の変位への当てはめに打ける天盤内 $1 \mathrm{~m}$ の変位は, 変 位が急速に增加する初期の段階には計測值とよく合った経時変化を 示すが, 時間の経過とともに, 計測值の方が大きくなっている。こ れは, 天盤内 $1 \mathrm{~m}$ の変位への当てはめとは逆の傾向であり, 天盤 内 $1 \mathrm{~m}$ 付近の岩盤には天盤内 $2 \mathrm{~m}$ および $3 \mathrm{~m}$ 付近の岩盤より大き なゆるみが発生し，初期コンプライアンスが天盤内 $2 \mathrm{~m}$ 抢よび $3 \mathrm{~m}$ 付近の岩盤より大きいことを示しているむのと思われる。

以上より,ここで提案している非線形粘弾性モデルによる坑道周 辺岩盤の变形解析法は, 岩盤が連続体として変形している場合には, 粘弾性的挙動を比較的短時間に，しかもある程度定量的に予测でき ることが分かった。

$3 \cdot 4$ 坑道のコンバージェンスのシミュレーション

$3 ・ 2$ に扔いて, 坑道壁面に最む近い天盤内 $1 \mathrm{~m}$ の鉛直変位の シミュレーション計算には $0.26 \mathrm{GPa}^{-1}$ の初期コンプライアンスを 用いればよいことが分かった。しかし，この場合，計算の開始時刻 は坑道が掘削された瞬間とし，その後の坑道周辺岩盤の变位を時間 の経過に伴って計算した。そして,この条件は松峰鉱山で行った坑 道のコンバージェンスの計測と同じである。そこで, 切羽が計測断 面を通過した直後から切羽後方で計測した坑道のコンバージェンス の経時変化と $0.26 \mathrm{GPa}^{-1}$ の初期コンプライアンスを用いて計算し たコンバージェンスの経時変化とを比較することにする。

Fig. 8 は坑道踏前（休）から $1.2 \mathrm{~m}$ の高さの水平方向のコンバー ジェンスの経時変化を表わしている。この中の○印は計測結果を, 点線は計算結果を示している。Fig. 8から明らかなように, 計測に よるコンバージェンスは時間の経過に伴って急速に増加した後, 緩 やかな増加に変化し, 増加の程度を減少させながら進展している。 一方, 計算によるコンバージェンスは, コンバージェンスが急速に 増加する約 25 日目までの経過時間においては, 計測值と定量的に あよく合っているが, コンバージェンスが緩やかな増加に変化した 約 25 日目以降は, 計算值の方が大きくなる傾向を示している。し かし, コンバージェンスの增加の割合は計算値と計測值の両方とも 時間の経過に伴って徐々に減少し,コンバージェンスの経時変化は

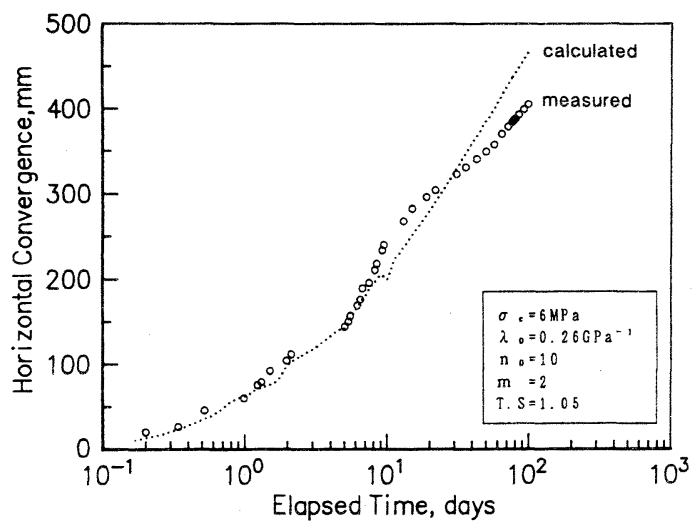

Fig. 8 Comparison between the measured and calculated holizontal covergence with logalithmic elapsed time; initial compliance was $0.26 \mathrm{GPa}^{-1}$. 


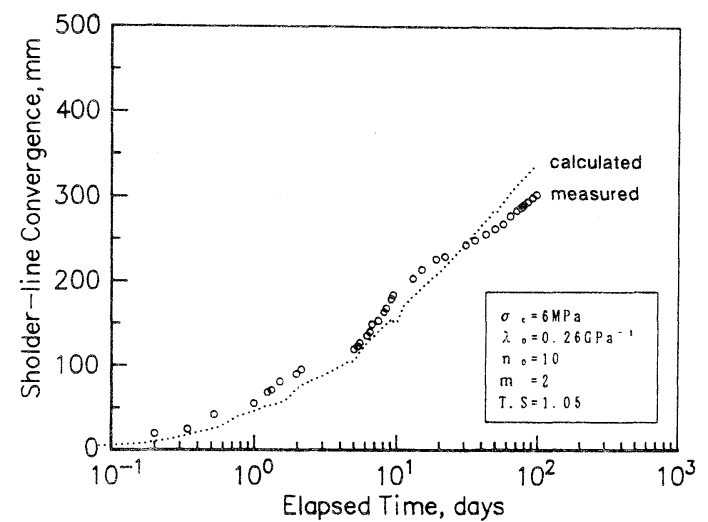

Fig. 9 Comparison between the measured and calculated shoulderline covergence with logalithmic elapsed time; initial compliance was $0.26 \mathrm{GPa}^{-1}$.

両者が同じ傾向を示している。

つぎに, 同じ断面の坑道肩部の斜め方向のコンバージェンスの計 测結果 (○印) とシミュレーションによる計算結果 (点線) を Fig. 9 に示す。なお, 計测値は坑道の左肩部と右肩部とで差異があるた め, ここでは左右肩部のコンバージェンスの平均值を代表值として 用いることにした。Fig. 9から明らかなように, 肩部のコンバージェ ンスの経時変化は, 計算結果, 計測結果ともに水平コンバージェン スとほぼ同様の傾向を示している。

このように, 水平方向と肩部の斜め方向の坑道断面の 2 方向のコ ンバージェンスについて, $0.26 \mathrm{GPa}^{-1}$ の初期コンプライアンスを 用いてシミュレーション計算を行った結果, コンバージェンスが急 速に増加する段階では, 計算值は計測值によく合うが, コンバージェ ンスが緩やかな増加に変化した後は, 計算值の方が計測值より大き くなる傾向を示す。

以上より，天盤内の鈆直変位への当てはめと同様に，ここで提案 している非線形粘弾性モデルによる坑道周辺岩盤の変形解析法は, 岩盤が連続体として変形している場合には, 粘弾性的挙動を比較的 短時間に，しかもある程度定量的に予測できることが分かった。

\section{4. 掘進を考慮した坑道天盤内変位のシミュレーション解析}

今回の 2 次元有限要素法によるシミュレーション計算では, 坑道 の掘削開始と同時に計算を始め，それ以降の変位の増分を計算した。 ところが, 松峰鉱山で計測した天盤内変位は, 切羽が計测断面を通 過するかなり以前から発生し, 時間の経過に伴って増加する過程を 辿っている。すなわち, シミュレーション計算では, 変形の開始時 刻は切羽が計測点を通過する時刻とほぼ一致しているが, 天盤内変 位の計測開始時刻とは一致しないことになり, 時間のみならず坑道 周辺の坑内構造の上からも両者の間に矛盾が生じる。この矛盾は, 平木鉱山の弾性的挙動を示す岩盤の変形挙動の解析で行ったように, 3 次元有限要素法によるシミュレーション計算によって解消するこ とが可能である。しかし, 現状では時間依存性の非線形粘弾性の変 形挙動を 3 次元有限要素法でシミュレーション計算を行うまでには 至っていないので, ここであ平木鉱山において用いた手法によって 坑道掘進を疑似的に模擬する方法 ${ }^{15)}$ を試みる。

まず, Fig. 10 に示すように, 坑道が未掘削状態の要素を用いて 計算し, 初期条件で坑道壁面の各要素に加わっている荷重 (坑道壁 面を支えるのに必要な内圧に相当する節点力との意味で, ここでは 等価節点力と呼ぶ) を求めた。Table 2 および Fig. 11 は坑道壁面 の初期等価節点力の大きさとその方向を示している。つぎに，この 等価節点力を減少させる割合を算定するため, 解析の対象とする断

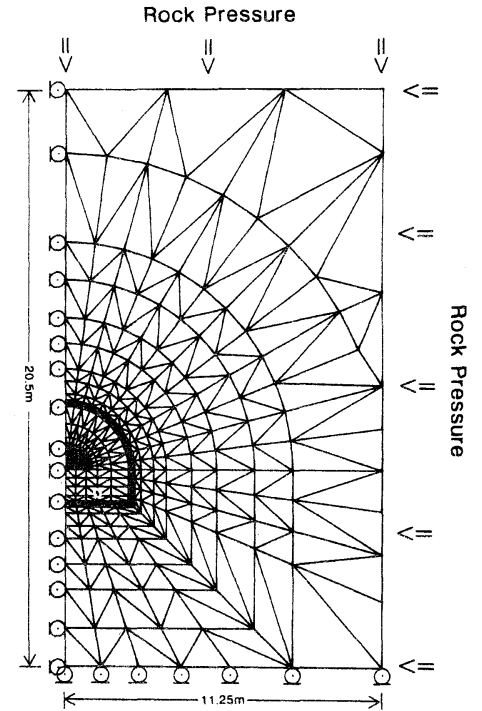

Fig. 10 Elements of FEM model before excavation.

Table 2 Magnitude of initial equivalent nodal force acted on elements around tunnel model.

\begin{tabular}{c|c|c}
\hline \multirow{2}{*}{ node number } & \multicolumn{2}{|c}{ initial equivalent nodal force $(\mathrm{N})$} \\
\cline { 2 - 3 } & Px & Py \\
\hline 1 & 0.00 & 1.12 \\
2 & 0.29 & 2.21 \\
3 & 0.58 & 2.16 \\
4 & 0.86 & 2.06 \\
5 & 1.12 & 1.93 \\
6 & 1.37 & 1.77 \\
7 & 1.59 & 1.58 \\
8 & 1.78 & 1.36 \\
9 & 1.95 & 1.12 \\
10 & 2.08 & 0.86 \\
11 & 2.18 & 0.58 \\
12 & 2.24 & 0.29 \\
13 & 2.27 & 0.07 \\
14 & 2.32 & 0.00 \\
15 & 2.45 & 0.00 \\
16 & 2.01 & 0.00 \\
17 & 0.75 & 2.37 \\
18 & 0.00 & 4.24 \\
19 & 0.00 & 3.47 \\
20 & 0.00 & 3.03 \\
21 & 0.00 & 2.81 \\
22 & 0.00 & 1.37 \\
\hline
\end{tabular}

note: compression is positive number

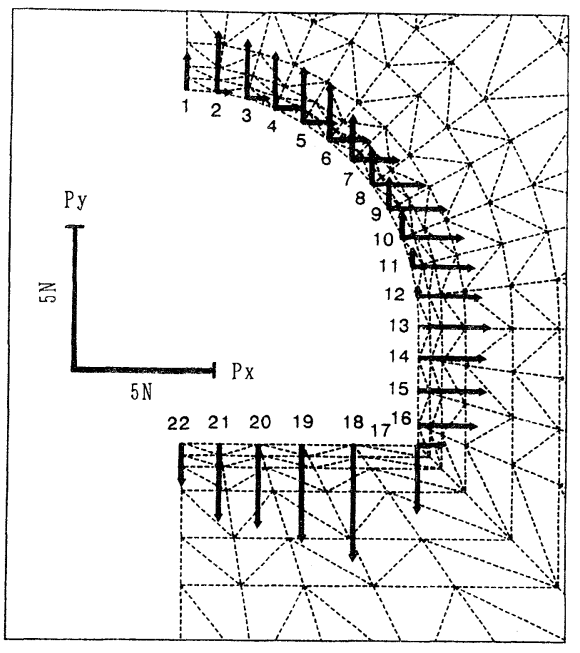

Fig. 11 Relationship between the face advanced distance from the initial position and elapsed time at Matsumine mine. 
面から切羽までの距離と等価節点力との関係を求めた。前述のよう に, 現在この関係を非線形粘弾性モデルによる 3 次元有限要素法で 解析することが難しいため，ここでは弾性的挙動を示す岩盤の変形 挙動の解析で得られた切羽進行距離と等価節点力を減少させる割合 との関係のうち，ポアンン比が 0.2 の場合を利用することにする ${ }^{15)}$ 。 一方, 松峰鉱山における切羽進行距離之時間の経過との関係は Fig. 12 のとおりであるので, これと弾性計算で得られた切羽進行 距離と等価節点力を減少させる割合との関係とから，松峰鉱山にお ける坑道壁面の各要素に加える等価節点力を減少させる割合を Fig. 13 のように設定し, これに従って坑道掘進を考慮したシミュ レーション計算を行った。このシミュレーション計算には Table 1 に示した標準的なパラメー夕群を用いた。ただし，これらのパラメー 夕群のうち, 初期コンプライアンスは天盤内 $1 \mathrm{~m}$ および $2 \mathrm{~m}$ の変 位の経時変化の当てはめに最むよく合った場合の値である 0.26 $\mathrm{GPa}^{-1}$ および $0.21 \mathrm{GPa}^{-1}$ のつのケースとした。

Fig. 14 は初期コンプライアンス $0.26 \mathrm{GPa}^{-1}$ を用いた計算結果 を示している。この図から明らかなように, 变位量は非常に小さい が, 天盤内変位は天盤内 $1 \mathrm{~m}, 2 \mathrm{~m}$ および $3 \mathrm{~m}$ のいずれの深さにお いても切羽前方で発生し, 切羽が計測断面を通過する時点から急速 に増加している。しかし, ある時間経過した後, 天盤内変位の増加 は急速に緩やかになる。この場合はシミュレーションによる計算値 を天盤内 $1 \mathrm{~m}$ の鈶直方向変位の計測值に当てはめた場合に対応し ているため, 天盤内変位の経時変化が天盤 $1 \mathrm{~m}$ において計算值と 計測值とが合うことは当然である。しかし，天盤内変位が急速に増

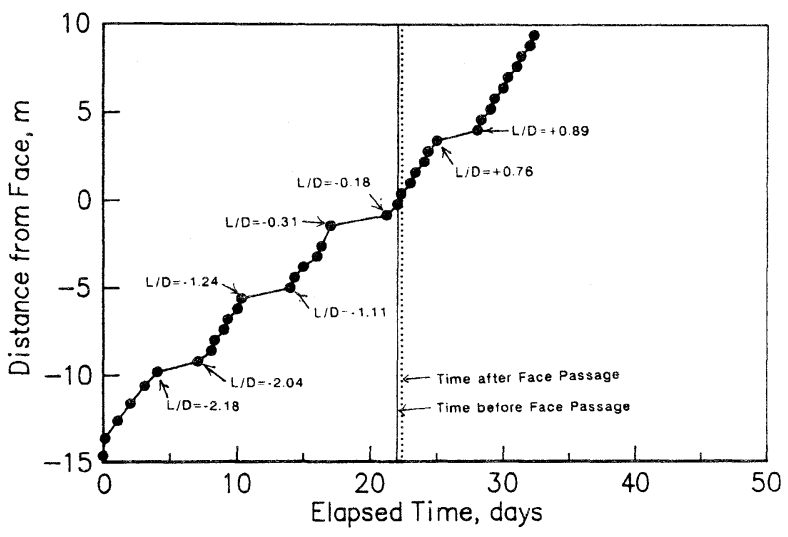

Fig. 12 Relationship between the reduction ratio of equivalent nodal force and the elapsed time; $L$ is the distance between face and measuring section, and $D$ is the face width.

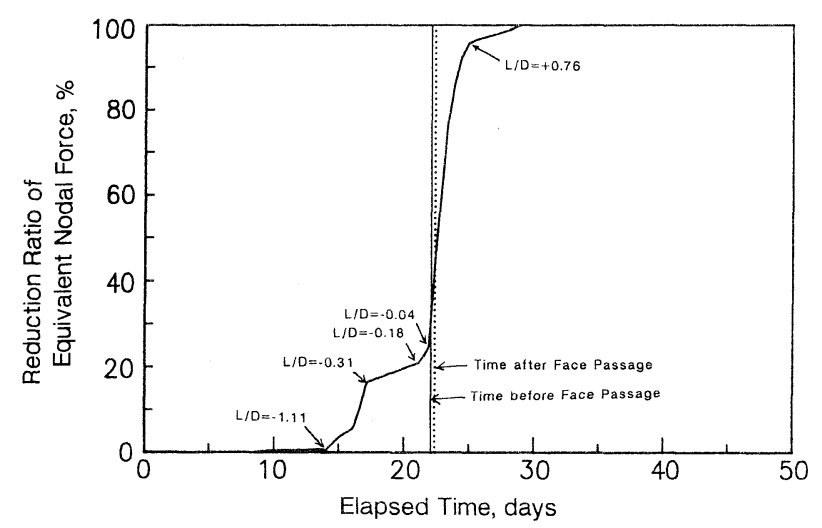

Fig. 13 The Magnitude and direction of initial equivalent nodal force on elements aruond tunnel; $L$ is the distance between face and measuring section, and $D$ is the face width.
加し始める時刻がシミュレーションによる計算結果と現場での計測 結果とでは時間上のズレが生じている。これは, 計算の場合は, 切 羽が計測点の直下を通過する直前の時刻には, Fig. 13 に示される ようにまだ約 $70 \%$ の支持荷重が切羽に残留しているため, 切羽前 方の天盤内には変位がほとんど発生しないのに対して, 実際の岩盤 の場合は, 切羽前方の岩盤には破壊の発生と粘性流動の広がりが推 測されること, また山富ら ${ }^{16)}$ の弾塑性解析によると, ひずみ軟化 特性を持つ岩盤の切羽が有する支持力は地圧の約 $20 \%$ に過ぎない ことから, 切羽前方の岩盤の支持荷重が相当低下し, このため, 天 盤内変位が急速に增加する時期は切羽のかなり前方にあることによ るものと思われる。

つぎに, 初期コンプライアンス $0.21 \mathrm{GPa}^{-1}$ を用いた計算結果を Fig. 15 に示す。Fig. 15 から明らかなように，天盤内変位は Fig. 7 と同様の経時変化を示し, 一方天盤内変位が急速に増加する時刻は Fig. 14 と同様に計算結果と計測結果の間に大きなズレが生じてい る。

以上のように, シミュレーションによる計算結果と現場での計測 結果との間には, 坑道周辺岩盤が急速に変形し始める時刻にズレが 生じたが, この原因として等価節点力（切羽支持荷重に相当）を減 少させる割合を弾性論で求めたことが挙げられる。すなわち, 弾性 論による計算では, 切羽前方の岩盤の変形は, もち万え弾性範囲内 にあると仮定したが, 計測を行った松峰鉱山の試験坑道周辺の実際 の岩盤では, 切羽前方に破壊領域またはゆるみ領域が広がっている と考无られることである。したがって, 今後, 非線形粘弾性モデル

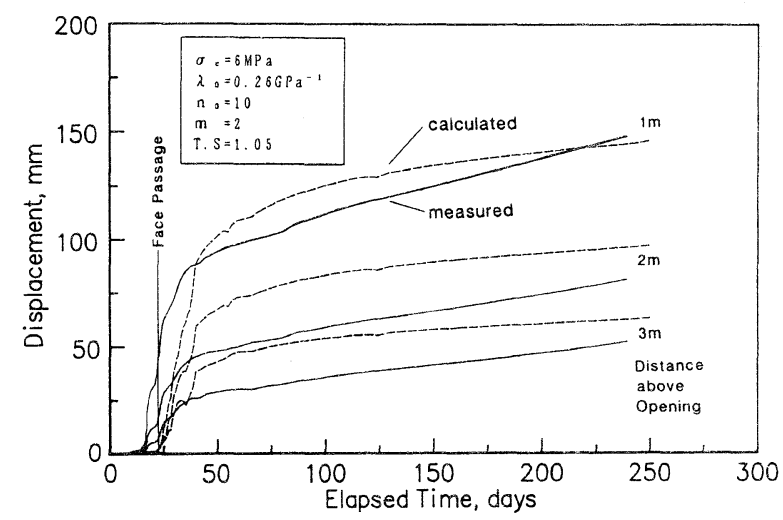

Fig. 14 Comparison between the measured and calculated vertical displacement in the roof being induced by face advance; initial compliance was $0.26 \mathrm{GPa}^{-1}$.

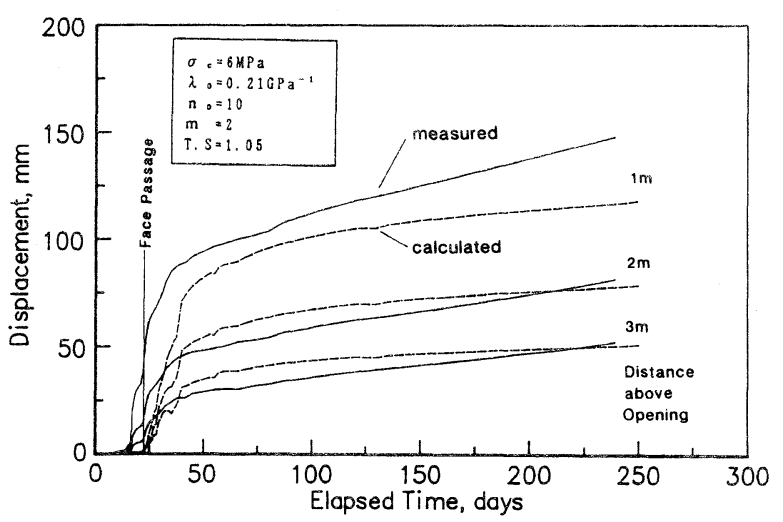

Fig. 15 Comparison between the measured and calculated vertical displacement in the roof being induced by face advance; initial compliance was $0.21 \mathrm{GPa}^{-1}$. 
によるシミュレーション解析によって，坑道掘進を考慮した岩盤の 変形挙動を定量的に議論するとすれば, 岩盤物性や切羽条件等を踏 まえ, 減少させる時期や割合等を 3 次元有限要素法によるシミュレー ション解析を行い, 確認することが必要である。

\section{5. 結}

\section{言}

粘弾性的挙動を示す軟弱な岩盤の時間依存性の変形挙動を解明し, また解析・評価することは，このような岩盤内での坑道やトンネル の設計・施工において重要なことである。これまでに, 種々の方法 で現場計測が行われ，また解析・評価方法が研究されているが，時 間に依存した变形を行う岩盤は非線形性が強く, 複雑な挙動を示す ため, その解明, 解析に多くの課題が残されている。

このため, 著者らはまず切羽前方で発生する先行変位を含めた岩 盤自体の变形を鉱山の坑道で計測し, 周辺岩盤の変形の時間依存性 および坑道掘進の影響を解明し, 評価を行った。一方, 非線形粘弾 性モデルを用いた 2 次元有限要素法による坑道周辺岩盤の時間依存 性の変形のシミュレーション解析とこの解析手法の評価を行うとと 屯に, 坑道掘進を考慮した変形挙動への 2 次元有限要素法の適用を 試みた。その結果，つぎのような点が明らかになった。

（1）非線形粘弾性モデルを用いた 2 次元有限要素法による解析 は, 入力する力学パラメー夕, 特に初期コンプライアンスを適正に 選ぶことにより, 坑道周辺岩盤の時間依存性の変形を比較的容易に, しかも定量的に表わすことができる。

（2） 2 次元有限要素法による坑道掘進を考虑した解析は可能で あるが, 切羽前方の破壊領域またはゆるみ領域の広がり，それらに よる切羽支持力の低下の割合等を非線形粘弾性モデルによる三次元 有限要素解析法で評価する必要がある。

（3）本非線形粘弾性モデルによる解析は, 岩盤が連続体として 挙動している変形に対しては適用できるが, 岩盤が不連続体として 挙動し始める時刻以降の大きな变形に対しては, 新たな解析手法が 必要である。

以上より，ここで提案している非線形粘弾性モデルによる坑道周
辺岩盤の変形解析法は, 岩盤が連続体しして変形する場合には, 時 間依存性挙動を比較的短時間に，しかもある程度定量的に予測でき る解析法であることが分かった。なお，今後は岩盤の不均質性の考 慮や不連続性の大变形を伴う岩盤を対象とした解析手法の開発が必 要である。

\section{引用 文 献}

1）例えば, 山口 勉・大久保誠介・西松裕一：日本鉱業会誌, Vol.100, p.631635, (1984)

2）例えば, 大久保誠介・西松裕一：日本鉱業会誌, Vol.102, p.395-400, (1986) Gioda, G. : Int. J. Rock Mech. Min. Sci. \& Geomech., Vol.18 [5] , p. $35-46$, (1981)

3) Adahi, T., and Takase, A. : Proc. of the Int. Symp. on weak rock, p.99104, (1981)

4）山冨二郎・山下 秀・緒方義弘 - 川辺金光 : Proc. of the 7th Japan Symposium on Rock Mechanics, p.p391-396, (1987)

5) Dawson, P.R., and Munson, D.E. : Int.J., Rock Mech. Min. Sci. \& Geomech., Vol.20 [1], p.33-34, (1983)

6) Sepehr, K. and Stimpson, B. : Int.J., Rock Mech. Min. Sci. \& Geomech., Vol.25 [6], p.383-392, (1988)

7) Sulem, J., Panet, M. and Guenot, A. : Int.J., Rock Mech. Min. Sci. \& Geomech., Vol.24 [3], p.145-154 \& p.155-164, (1987)

8) Otsuka, M. and Kondoh, T. : Proc. of the Int. Symp. on weak rock, p.945 -950 (1981)

9）緒方義弘・冨島康夫・大久保誠介・西松裕一：資源之素材, Vol.109, p.171178, (1993)

10）緒方義弘・富島康夫・大久保誠介・西松裕一：資源之素材, Vol.109, p.853860, (1993)

11）大久保誠介・阿昌栄・西松裕一：日本鉱業会誌, Vol.103, p.177-181, (1987)

12）大久保誠介・西松裕一・緒方義弘：日本鉱業会誌, Vol.103 [1191]，p.293296, (1987)

13) Janach, W. : Int. J. Rock Mech. Min. Sci. \& Geomech., Vol.14 [3], p.209$215,(1977)$

14）緒方義弘 - 山口 勉 -大久保誠介：資源・素材 91 , (秋季大会), M-7, p. $25-28,(1991)$

15）緒方義弘・酎川道雄・谷波正三：資源と素材，Vol.107，p.467-475，(1991）

16）山冨二郎・茂木源人・山下 秀・山口梅太郎：資源・素材学会研究・業績発 表講演要旨集, p.81-82, (1990) 